\title{
Relevance of the person-environment fit approach to career assessment in South Africa - A review
}

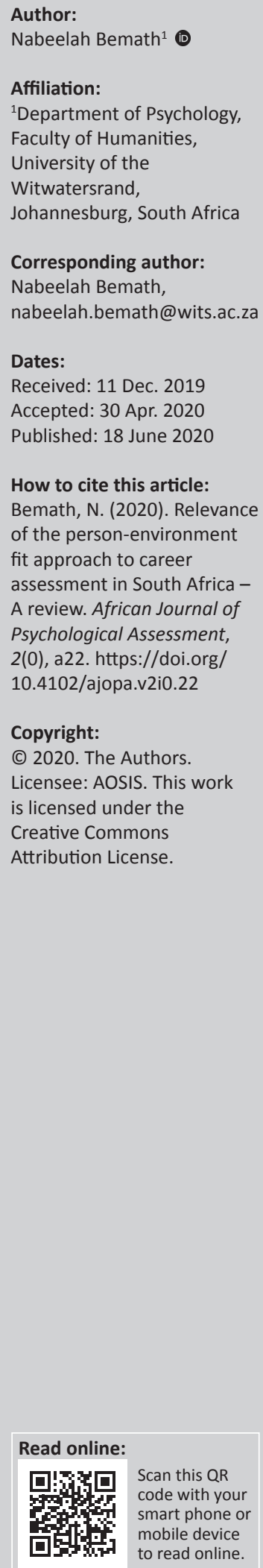

Despite concerns regarding its relevance, the person-environment fit approach to career counselling assessment remains a popular one in the South African context. This may be due to a lack of awareness of, or regard for, these concerns among career counselling assessment practitioners working in South Africa. This narrative review thus aimed to summarise literature regarding the relevance of the person-environment fit approach to career counselling assessment in South Africa and alternatives to this approach. Keywords were used to search for, and identify, literature on several electronic databases. Additional literature was identified through citations and citing publications in the initial literature obtained. Given the nature of a narrative review, no inclusion, exclusion or appraisal criteria were specified. Based on the review of literature, the following themes and subthemes were identified: questionable relevance of the person-environment approach (inadequate reliability and validity of tests in the South African context, Western-based theoretical underpinnings, language and socioeconomic bias, and inadequate norms for the South African context) and alternative directions of career counselling assessment in this context (development of emic tests, qualitative assessment approaches and integrated assessment approaches). The findings suggest that an integrated quantitative-qualitative approach to career counselling assessment may be a feasible alternative to the person-environment fit approach. However, further research and development regarding the person-environment fit approach and other career counselling assessment approaches is required in order to move towards a more relevant career counselling assessment practice in South Africa.

Keywords: Person-environment fit approach; career assessment; career counselling; relevance; South Africa.

\section{Introduction}

The person-environment fit approach to career counselling assessment is widely used in the South African context (Watson \& McMahon, 2013). This approach requires the client to know themselves and the world of work, and thus find a fit between the two to make an appropriate career-related decision (De Bruin \& De Bruin, 2013). To achieve this, assessment is conducted using the following categories of psychological tests: cognitive or aptitude, personality, interests and values (De Bruin \& De Bruin, 2013). However, challenges in using this approach to career counselling assessment in South Africa (e.g. De Bruin \& De Bruin, 2013; Maree \& Beck, 2004) suggest that the relevance of this approach in this context is questionable. What is problematic is that many career assessment practitioners in South Africa remain unware of, or ignore, these issues (Maree, 2013; Watson \& Stead, 2002). There is thus a need for a scholarly summation of the relevance of this approach in the South African context. Findings from such a summation may contribute to knowledge of the relevance of this approach in South Africa and potentially facilitate the awareness, development and practice of a more contextually relevant assessment practice in this context. This narrative review thus aimed to describe literature regarding the relevance of the person-environment fit approach to career counselling assessment in South Africa, with a focus on literature pertaining to specific aptitude, personality and interest tests that are commonly used in this context, namely, the Differential Aptitude Test (DAT) which assesses aptitude in terms of potential to obtain an ability with a given degree of training, the 16 Personality Factor Questionnaire $(16 \mathrm{PF})$ which measures personality in terms of 16 primary personal traits and the relationship between these through five underlying second-order factors, and the Self-Directed Search (SDS) which assesses interests using six broad domains of interest as per Holland's theory of vocational personalities and work environment (Du Toit \& De Bruin, 2002; Foxcroft, Paterson, Le Roux, \& Herbst, 2004; Van Eeden, Taylor, \& Prinsloo, 2013). The objectives of this review are (1) to identify, summarise and describe literature regarding the psychometric properties and use of the DAT, 16PF and SDS for career counselling assessment in the South African context, (2) to appraise the 
relevance of the person-environment fit approach in this context using the above-mentioned literature and (3) to identify and describe alternative approaches to the personenvironment fit approach to career counselling assessment in South Africa.

\section{Methods}

A narrative literature review was conducted. This comprised an examination of published literature on a broad topic, in order to consolidate and summarise information on that topic and identify gaps in the knowledge area that need to be addressed (Grant \& Booth, 2009). In contrast to systematic reviews, which aim to provide a comprehensive synthesis of knowledge on a topic, narrative reviews do not entail a structured approach to the search and selection of literature to include and review (Grant \& Booth, 2009; Greenhalgh, Thorne, \& Malterud, 2018). For this reason, an exhaustive and detailed search process was not adopted and reported for the current review. This review used combinations of keywords such as 'person-environment fit approach South Africa', 'career assessment South Africa' and '16 Personality Factor Questionnaire South Africa' to search for and identify literature, on several electronic databases (e.g. Sabinet, EbscoHost) and the search engines Google and Google Scholar. Articles that addressed the above-mentioned objectives were included. Further relevant literature was identified through consulting the citations and citing publications of the initial literature obtained. Themes across the literature obtained were identified and are presented.

\section{Ethical consideration}

This article followed all ethical standards for research without direct contact with human or animal subjects.

\section{Review findings \\ Questionable relevance of the person- environment approach to career assessment in South Africa}

Although the DAT, 16PF and SDS are used widely in South Africa, research pertaining to these tests raises concerns regarding their relevance (and thus the relevance of the person-environment fit approach) in this context (see De Bruin \& Taylor, 2013; Gevers, Du Toit, \& Harilall, 1995; Van Eeden \& De Beer, 2013; Van Eeden et al., 2013). Based on the literature, the relevance of this approach can be considered in terms of the following subthemes: inadequate reliability and validity of tests in the South African context, Western-based theoretical underpinnings, language and socio-economic bias, and inadequate norms for the South African context.

\section{Inadequate reliability and validity of tests in the South African context}

The existing evidence for the DAT (Coetzee \& Vosloo, 2000; Owen, 2000; Patel, 2004), 16PF (McDonald \& Van Eeden, 2014; JvR Academy, n.d; JvR Psychometrics, 2011; Schepers \& Hassett, 2006) and SDS (Du Toit \& De Bruin, 2002; Gevers et al., 1995) generally indicate that these tests demonstrate good reliability and validity. However, minimal research has explored the psychometric properties of these tests, particularly the DAT and SDS, in South Africa. A search on Google, Google Scholar and the search engines linked to EbscoHost using the search terms of 'Differential Aptitude Test South Africa', 'DAT', 'DAT South Africa', 'aptitude tests in South Africa' and variations of the same indicated that there is a paucity of research on all four forms of the DAT and consequently its psychometric properties. Literature has also specifically argued that little research has explored the reliability and validity of Form $\mathrm{K}$ of the DAT (Laher \& Mokone, 2008). Similarly, there is limited evidence of the psychometric properties of the SDS in South Africa (Du Toit \& De Bruin, 2002; Watson, Foxcroft, \& Allen, 2007). This indicates that support for the reliability and validity of these tests in this context is lacking.

Furthermore, evidence suggests that the psychometric properties of the DAT, 16PF and SDS may not replicate across different subgroups, rendering the relevance of the tests in South Africa questionable. Firstly, research pertaining to the cross-cultural validity of these tests is concerning. Minimal research has explored the equivalence of cognitive tests (like the DAT) (Meiring, Van De Vijver, Rothmann, \& Barrickvan, 2005) and the SDS across groups within the South African context (Allen, 2005; Du Toit \& De Bruin, 2002; Watson et al., 2007). This raises concerns regarding the suitability of the DAT and SDS in South Africa's multicultural context. While there is a more substantial body of evidence regarding the cross-cultural validity of the 16PF in South Africa (see De Bruin \& Taylor, 2013; JvR Psychometrics, 2011), some research does not support its cross-cultural validity in this context (Abrahams, 2002; Abrahams \& Mauer, 1999b; JvR Academy, n.d.; Schepers \& Hassett, 2006; Van Eeden, Taylor, \& Du Toit, 1996, as cited in Van Eeden et al., 2013). This suggests that the test may be culturally biased (see JvR Academy, n.d.; Meiring et al., 2005; Prinsloo \& Ebersöhn, 2002). The cross-cultural applicability of the 16PF and SDS is particularly concerning as these tests were originally developed in Western contexts (Maree, 2013).

\section{Western-based theoretical underpinnings}

The theoretical underpinnings of the 16PF and SDS further suggest that these tests may be culturally biased in South Africa. The 16PF may be culturally biased in South Africa as indigenous manifestations of personality may not be measured in Western-based tests (Van Eeden \& Mantsha, 2007). People from non-Western backgrounds may attach different meanings to the constructs being assessed by this test (Van Eeden \& Mantsha, 2007). For example, research suggests that the Warmth factor in the $16 \mathrm{PF}$ does not manifest within the Tshivenda culture in terms of open expression of feelings, as they are an emotionally reserved culture (Van Eeden \& Mantsha, 2007). Similarly, the cultural validity and relevance of Holland's model and the SDS in South Africa is questionable as the meaning ascribed to the six broad interests of Holland's model in this context may differ from that in the 
USA (Du Toit \& De Bruin, 2002). For example, the collectivistic value of 'ubuntu' (which emphasises helping others over oneself) can alter the meaning ascribed to career interests (Du Toit \& De Bruin, 2002). Interests may play less of a role in cultures that value ubuntu, in comparison to cultures where individualism is emphasised (Du Toit \& De Bruin, 2002). The limited research that has explored the suitability of the SDS and Holland's theory in South Africa is equivocal, with some research supporting the cross-cultural validity of Holland's model in South Africa while other research does not (see Du Toit \& De Bruin, 2002; Morgan, De Bruin, \& De Bruin, 2015a, 2015b; Watson et al., 2007). Consequently, the relevance of Holland's theory and the SDS for certain South African population groups is questionable (Du Toit \& De Bruin, 2002; Morgan et al., 2015b) and its use can result in unfair treatment of clients (Morgan \& De Bruin, 2017).

\section{Language and socio-economic bias}

Research further suggests that the DAT, 16PF and SDS may be biased in terms of language. As test-takers who are completing a psychometric test in a second language tend to first mentally translate a test question into their home language and then select an answer, the performance of second language test-takers on the DAT (a timed test) may be negatively affected by this process (Kgosana, 2017). This is supported by South African research which found population mean score differences on the precursor to the DAT-K (Owen, 1991, as cited in Laher \& Mokone, 2008) and significant differences in performance on the DAT-K between English and African first language Black South African students (Laher \& Mokone, 2008). Research conducted with the latter sample also found the coefficients for the verbal subtests to be lower than those reported in the test manual (Laher \& Mokone, 2008). South African students have also criticised the language used in the DAT-K (Bischof \& Alexander, 2008). English language proficiency has also been shown to differentiate between learners' scores on the DAT-S (MacFarlane, 2006). Second language test-takers may thus perform lower than first language test-takers (MacFarlane, 2006); this is a concern since the DAT is available in only two of the 11 official languages in South Africa (English and Afrikaans; Differential Aptitude Tests - Forms R, S, K and L, n.d.). These lower scores would be a function of the language of the test and not their cognitive functioning (Kgosana, 2017), making it difficult to know if test results reflect language problems or actual ability (Laher \& Cockcroft, 2013). Similarly, language competency has been said to affect South African test-takers' responses to the 16PF (JvR Academy, n.d.). Research investigating the understanding of vocabulary used in the 16PF-SA92 (Abrahams \& Mauer, 1999a) and 16PF5 (McDonald \& Van Eeden, 2014) found that first language English and Afrikaans speakers scored significantly higher than second language speakers. Poor internal consistency reliability coefficients were also found on the 16PF5 among a sample of Tshivenda first language speakers (Van Eeden \& Mantsha, 2007). The findings suggest that the test may be biased against second language English or Afrikaans speakers, where language proficiency affects test performance (Abrahams \& Mauer, 1999a; McDonald \& Van Eeden, 2014). This may also account for the lack of construct equivalence found across language groups (Meiring et al., 2005; Van Eeden \& Mantsha, 2007) While translation of the test into different languages may address these issues, attempts to translate the 16PF5 into Zulu and Tshivenda have faced several challenges. These challenges included: the presence of different Zulu dialects across different regions, retaining the original meaning of test items and the absence of equivalent words and expressions in Zulu and Tshivenda (JvR Academy, n.d.; McDonald \& Van Eeden, 2014; Van Eeden \& Mantsha, 2007). The difficulty in translating these tests so that they are appropriate for the South African context raises further concern regarding the test's relevance in this context. The SDS may also suffer from language bias, which casts doubt on the relevance of this test in South Africa. Research showing poor fit between South African test-takers' SDS scores and Holland's model has been argued to be a function of test-takers experiencing difficulty in fully comprehending the meanings of test items (Du Toit \& De Bruin, 2002).

The effect of socio-economic factors on scores obtained on the DAT, $16 \mathrm{PF}$ and SDS also raises concern regarding the relevance of these tests in South Africa. In terms of the DAT, the measurement of aptitudes assumes that everyone who has taken the measure has had the same exposure to these aptitudes; however, this may not necessarily be the case (Puchert, Dodd, \& Viljoen, 2017; Van Eeeden \& De Beer, 2013). Students from disadvantaged educational backgrounds are unlikely to have been exposed to the same knowledge and skills as students from advantaged backgrounds (Kgosana, 2017). Although the DAT-K is suitable for learners from disadvantaged educational backgrounds (Laher \& Mokone, 2008), this may negatively affect performance on cognitive tests like the DAT (Puchert et al., 2017). These results may be erroneously interpreted as poor cognitive ability as opposed to lack of skills or experience in comparison to advantaged peers, possibly leading to the unfair use and interpretation of test results (Puchert et al., 2017). Insufficient exposure and disadvantaged educational background have also been reported to affect performance on the 16PF5, where this had led to tests-takers experiencing difficulty with certain items (Van Eeden \& Mantsha, 2007). Socioenvironmental factors may also partly affect SDS tests scores. The apartheid legacy of social inequality and employment and other labour conditions (which are likely to differ to those found in Western contexts) may shape how test-takers in South Africa perceive the world of work and thus respond to the SDS (Du Toit \& De Bruin, 2002; Morgan \& De Bruin, 2017; Van Wijk \& Fourie, 2017; Watson, McMahon, \& Longe, 2011). For example, socio-economic status may be a more influential factor in South Africans' career decisions than career interests (Van Wijk \& Fourie, 2017). These factors may yield response patterns that depict poor fit between the test results and Holland's model (Du Toit \& De Bruin, 2002; Morgan et al., 2015a). These tests thus do not consider the impact that sociocultural factors have on career-related decisions. 
Given the possible biases and challenges faced in using the DAT, 16PF and SDS in South Africa, the relevance of these tests in this context is thus questionable. This is particularly because this can lead to test results that provide unreliable and invalid reflections of test-takers, which can in turn lead to inappropriate career guidance and counselling (McDonald \& Van Eeden, 2014; Prinsloo \& Ebersöhn, 2002; Wallis \& Birt, 2003).

\section{Inadequate norms for the South African context}

The relevance of the DAT, 16PF and SDS is further questionable given the issues regarding the norms of these tests. The norms for the DAT and SDS can be considered outdated. In terms of the DAT, the most recent norms available for most DAT forms were published in 2000 (Differential Aptitude Tests - Forms R, S, K and L, n.d.). In terms of the SDS, the South African version of the test is outdated (a problem in and of itself as the test does not align with the current world of work), thus suggesting that the norms are outdated as well (Du Toit \& De Bruin, 2002; Van Wijk \& Fourie, 2017). This is concerning as outdated norms do not align with societal changes that affect test performance and thus can result in inaccurate or non-meaningful interpretations (Kaplan \& Saccuzzo, 2017). Furthermore, information available on the norms of the DAT and 16PF suggest that these norms are not representative of the South African population (see Differential Aptitude Test Form K, n.d.; JvR Academy, n.d.; JvR Psychometrics, 2016). The standardisation of these tests also failed to consider factors that influence test scores such as quality of education and language (Kgosana, 2017; Wallis \& Birt, 2003). This is problematic as these issues can also lead to erroneous, negative interpretation and use of test scores (Kaplan \& Saccuzzo, 2017).

\section{Alternative approaches to career counselling assessment in South Africa}

Considering the challenges currently facing the person approach to career counselling assessment in South Africa, alternative approaches to career counselling assessment in this context have been proposed to enable a more relevant assessment practice (Maree, 2013; Watson \& Stead, 2002). The following subthemes were identified: Development of emic tests, qualitative assessment approaches and integrated assessment approaches.

\section{Development of emic tests}

For instance, researchers and practitioners have engaged in developing and implementing new and contextually relevant assessments that can be utilised in career counselling (Maree, 2013; 2016; McDonald \& Van Eeden, 2014). Some examples of such tests are the South African Personality Inventory (Van Eeden \& Mantsha, 2007) and local interest instruments like the Maree Career Matrix and South African Career Interest Inventory (Maree \& Taylor, 2016; Morgan et al., 2015a, 2015b). These instruments are not without limitations. For example, despite the South African Career Interest Inventory being a few years into development, research on the South African
Career Interest Inventory is limited by unrepresentative, homogenous and small samples, and issues of bias and validity require further exploration (Morgan et al., 2015a, 2015b). Research regarding the possible cultural and linguistic biases of these tests is also lacking (Allen, 2005; Maree, 2010; Rabie \& Naidoo, 2019). Hence, the relevance of these tests is not well established.

\section{Qualitative assessment approaches}

Another alternative to the person-environment fit approach is the adoption of qualitative approaches to career counselling assessment (Albien \& Naidoo, 2016; Morgan, 2010). Unlike the quantitative tests that comprise the person-environment fit approach, qualitative approaches allow for the effect of socio-environmental factors on career development in the country to be considered (Albien \& Naidoo, 2016; Buthelezi, Alexander, \& Seabi, 2009). These approaches additionally provide the client with an opportunity to take on a more active role in the assessment, helping them to gain exposure to skills that they can use in future career-related decisions and thus develop themselves (Morgan, 2010; Watson \& McMahon, 2013). In doing so, it removes the notion that assessment practitioners are the all-knowing experts (Maree, 2015), a notion that can have negative implications given the political history of assessment in South Africa (Bischof \& Alexander, 2008). There are various qualitative approaches that have been put forward. For instance, the Systems Theory considers the role of intrapersonal, interpersonal and broader socio-environmental elements in clients' career development, and can make use of appropriate qualitative assessment instruments such as the My System of Career Influences (Albien \& Naidoo, 2016; De Bruin \& De Bruin, 2013). Similarly, the Career Construction Theory focuses on clients' life themes and construction of themselves and their careers. An offshoot of this theory is life-design counselling, which focuses on clients' life and career narratives (Cook \& Maree, 2016). Examples of instruments that can be used in these approaches are: the Career Style Interview (which is used to encourage clients to narrate and find meaning in their career stories; De Bruin \& De Bruin, 2013) and the narrative component of the Career Interest Profile (a locally developed qualitative instrument that provides narrative data regarding the client's career interests; Maree, 2017).

It should be noted that while qualitative assessment approaches help to address some of the limitations of the personenvironment approach, this does not negate the utility of quantitative psychometric tests (Di Fabio \& Maree, 2013; Morgan, 2010). There are other limitations pertaining to the above-mentioned qualitative assessment approaches. For example, although the My System of Career Influences has been successfully used with South African clients, improvements are required particularly in terms of translating the instrument into different official languages (see Albien \& Naidoo, 2016; Watson \& McMahon, 2013). There is also a lack of locally relevant qualitative assessments that have been developed (Maree \& Beck, 2004; Watson \& McMahon, 2013). An additional limitation of these qualitative approaches is that 
they can be time and labour intensive (Maree \& Beck, 2004; Watson \& McMahon, 2013).

\section{Integrated assessment approaches}

An alternative approach to career counselling assessment that has more recently been advocated for is the integration of quantitative and qualitative assessment approaches (Maree, 2015, 2017). An integration of quantitative and qualitative approaches would involve obtaining clients' objective psychometric test scores and subjective accounts of their career and life stories (Maree, 2015). Information obtained from both approaches is then combined and drawn upon together during the counselling process (Watson \& McMahon, 2013). This integration can be facilitated using instruments such as the Career Interest Profile, which comprises both quantitative and qualitative components (Di Fabio \& Maree, 2013).

The integration of quantitative and qualitative approaches to assessment provides a comprehensive approach that will best meet the needs of clients (Maree \& Morgan, 2012). It allows for assessment results to be triangulated, thus eliciting more reliable and valid results (Maree, 2013; 2015). In this way, the limitations of using older assessment approaches or using quantitative and qualitative approaches in isolation within the South African context may be addressed (Maree, 2010; Maree \& Beck, 2004). Some studies have conducted research using an integrated assessment approach (cf. Maree, 2014, 2018, 2019; Maree, Gerryts, Fletcher \& Olivier, 2019; McMahon, Watson, \& Zietsman, 2018; Naidoo et al., 2019). While these show the promise of an integrated assessment approach to career counselling in the South African context, these studies are limited by the lack of longitudinal research, lack of translated instruments or use of translators with samples who are non-English first language speakers, use of a few specific quantitative and qualitative assessments, and lack of diverse samples.

\section{Implications and recommendations}

Based on the problems discussed in relation to the DAT, 16PF and SDS, it appears that these tests may not be relevant in this context. In their current forms, these tests appear to be culturally and linguistically biased and do not consider the subjective experiences of clients where external factors shape career-related decisions (De Bruin \& De Bruin, 2013; Maree, 2015; Van Wijk \& Fourie, 2017). Using these tests on their own, and by implication the person-environment fit approach, for career counselling assessment may be inappropriate and potentially harmful in this context (Bischof \& Alexander, 2008; Watson et al., 2007). Indeed, this approach has previously been critiqued in this regard (De Bruin \& De Bruin, 2013; Maree, 2015). Although there has been some development of contextually relevant tests that can be used for career counselling assessment, the persistent popularity of the person-environment fit approach in South Africa indicates that there is a need for existing tests to be updated and adapted (Maree, 2013; 2016). The use of flexible assessment practices, further research and development of emic instruments are also encouraged (cf. Laher \& Cockcroft, 2017; Watson \& McMahon, 2013).

Of the alternatives to the person-environment fit approach that were identified in the literature, the integrated approach appears to be the more suitable alternative given its comprehensive nature. However, merely integrating quantitative and qualitative approaches may be insufficient for several reasons. Integrating quantitative and qualitative approaches without addressing the limitations present in each approach is problematic. Issues such as the need to translate instruments into the different official languages and to develop locally relevant assessments would still apply. Integrating quantitative and qualitative assessments thus does not resolve the issue of language bias in career counselling assessment. Assessments used in both approaches would need to be evaluated for this, and may require translation or the assistance of appropriately trained translators when assessing clients who are non-English first language speakers (cf. Naidoo et al., 2019). Similarly, the theoretical frameworks and constructs that underpin the chosen integrated approach also need to be evaluated for their suitability within the South African context (cf. Arthur \& McMahon, 2018).

Careful consideration of the appropriateness of the assessments chosen when using an integrated approach in the South African context is thus necessary, whether this be an alternative assessment such as the Career Interest Profile (Di Fabio \& Maree, 2013) or integration of individual quantitative and qualitative assessments. Additional considerations may be required for possible qualitative assessments, as research and evidence regarding qualitative career counselling assessments is limited, with most existing research lacking in rigour (McMahon, 2019) and located in Western contexts (McMahon, Watson, \& Lee, 2019). Assessments that have been evaluated in the South African context should preferably be used. Further research would also be required on etic qualitative assessments that have not been evaluated in this context, and emic assessments that have not been evaluated across diverse groups. Some qualitative career counselling assessments are also located within a positivist paradigm, and thus may not complement the quantitative assessment in providing the coconstruction of realities traditionally associated with the use of qualitative assessments (McMahon, 2019). The underlying paradigm and framework of the chosen assessment would thus also need to be considered. The choice of quantitative assessments is no less important, as quantitative scores may determine the interpretation of the qualitative assessment results (cf. McMahon et al., 2018). If the quantitative assessment is psychometrically concerning in the South African context, this may problematically impact the interpretation and application of the integrated assessment results. Therefore, without addressing the limitations of the quantitative and qualitative approaches, and carefully selecting the assessments to be used in an integrated approach, it is unlikely that one approach would compensate for the limitations of the other despite being used in an integrated manner. 
Further research regarding the use of an integrated approach in the South African context is also required, as this body of research appears to be minimal and has several limitations (c.f. Maree, 2014, 2018, 2019; Maree et al., 2019; McMahon et al., 2018; Naidoo et al., 2019). The rigour of an integrated approach is also said to be unclear (see Maree, 2018), suggesting this too needs to be evaluated. Another matter that needs to be addressed is practitioners' tendency to disregard calls for using an integrated approach, which is often linked to lack of knowledge and guidance, or concerns, regarding qualitative approaches (Maree, 2013; McMahon, 2019). In addition, practitioners in South Africa may experience difficulty in integrating these approaches given the additional time and resources required in incorporating a qualitative approach (Maree \& Beck, 2004). Hence it is unlikely that practitioners will rely on both approaches. There is thus a need for the education and training of students and practitioners in both qualitative and integrated approaches. User guides to these approaches in the South African context may also require development. Given the resource demands of an integrated approach, coupled with the minimal number of psychological practitioners in South Africa and inaccessibility to career counselling assessment in lower socio-economic contexts in the country (cf. Maree et al., 2019), the feasibility of the approach in the South African context also needs evaluation. While the integrated approach to career counselling assessment thus appears to be a suitable alternative to the person-environment fit approach in South Africa, further research, development and education regarding this approach is required.

\section{Conclusion}

Given the person-environment fit approach's reliance on primarily Eurocentric, outdated psychometric tests whose psychometric properties and cross-cultural applicability are concerning in the South African context, the relevance of this approach to career counselling assessment in this context is questionable. Alternatives to this approach also have several limitations. These concerns suggest that researchers and practitioners involved in career counselling assessment need to engage in test adaptation and development, address limitations present in current quantitative and qualitative approaches to assessment, educate students and professionals to critically engage with both approaches when conducting career counselling assessment, and conduct methodologically rigorous research regarding the feasibility and effectiveness of an integrated approach. In doing so, there may be a more reliable, valid, relevant and fairer practice of career counselling assessment in South Africa that can better address the vocational needs of its population.

\section{Acknowledgements Competing interests}

The author declares that she has no financial or personal relationships that may have inappropriately influenced her in writing this article.

\section{Author's contributions}

I declare that I am the sole author of this article.

\section{Funding information}

No funding was received for this article.

\section{Data availability statement}

Data sharing is not applicable to this article as no new data were created or analysed in this study.

\section{Disclaimer}

The views expressed in the submitted article are the author's own and not an official position of the institution or funder.

\section{References}

Abrahams, F. (2002). The (un) fair usage of the 16PF (SA92) in South Africa: A response to $\mathrm{CH}$ Prinsloo and I. Ebersöhn. South African Journal of Psychology, 32(3), 58-61. https://doi.org/10.1177/008124630203200308

Abrahams, F., \& Mauer, K.F. (1999a). Qualitative and statistical impacts of home language on responses to the items of the Sixteen Personality Factor Questionnaire (16PF) in South Africa. South African Journal of Psychology, 29(2), 76-86. https:// doi.org/10.1177/008124639902900204

Abrahams, F., \& Mauer, K.F. (1999b). The comparability of the constructs of the 16PF in the South African context. South African Journal of Industrial Psychology, 25(1), 53-59. https://doi.org/10.4102/sajip.v25i1.679

Albien, A.J., \& Naidoo, A.V. (2016). Social career influences of Xhosa adolescents elicited using the systems theory framework in a peri-urban South African township. South African Journal of Higher Education, 30(3), 111-137. https://doi. org/10.20853/30-3-668

Allen, L.J. (2005). The appropriateness of Holland's Interest code typology for South African field guides. Unpublished masters thesis, Nelson Mandela Metropolitan University, Durban.

Arthur, N., \& McMahon, M. (2018). Contemporary career development theories: Expanding international perspectives. In N. Arthur \& M. McMahon (Eds.), Contemporary theories of career development (pp. 241-257). New York, NY: Routledge.

Bischof, D., \& Alexander, D. (2008). Post-modern career assessment for traditionally disadvantaged South African learners: Moving away from the 'expert opinion'. Perspectives in Education, 26(3), 7-17.

Buthelezi, T., Alexander, D., \& Seabi, J. (2009). Adolescents' perceived career challenges and needs in a disadvantaged context in South Africa from a social cognitive career theoretical perspective. South African Journal of Higher Education, 23(1), 505-520. https://doi.org/10.4314/sajhe.v23i3.51033

Coetzee, M.A., \& Vosloo, H.N. (2000). Manual for the differential aptitude tests form K. Pretoria: Human Sciences Research Council.

Cook, A., \& Maree, J.G. (2016). Efficacy of using career and self-construction to help learners manage career-related transitions. South African Journal of Education 36(1), 1225. https://doi.org/10.15700/saje.v36n1a1225

De Bruin, G.P., \& De Bruin, K. (2013). Career counselling assessment. In C. Foxcroft \& G. Roodt (Eds.), Introduction to psychological assessment in the South African context (4th edn., pp. 201-212). Oxford University Press Southern Africa Cape Town.

De Bruin, G.P., \& Taylor, N. (2013). Personality assessment. In C. Foxcroft \& G. Roodt (Eds.), Introduction to psychological assessment in the South African context (4th edn., pp. 185-200). Oxford University Press Southern Africa, Cape Town.

Di Fabio, A., \& Maree, J.G. (2013). Career counselling: The usefulness of the Career Interest Profile (CIP). Journal of Psychology in Africa, 23(1), 41-49. https://doi.org/ 10.1080/14330237.2013.10820592

Differential Aptitude Test (DAT) Form K - 2008 Edition. (n.d.). Retrieved from http:// www.mindmuzik.co.za/index.php?page=shop.product_details\&flypage=flypage tpl\&product_id=149\&_category_id=3\&option=com_virtuemart\&Itemid=78

Differential Aptitude Tests - Forms R, S, K and L (DAT). (n.d.). Retrieved from http:// $\mathrm{mind}$ muzik.com/index.php? page $=$ shop.product_details\&category id=3\&flypage=flypage.tpl\&product_id=150\&option=com_virtuemart\&Itemid=78

Du Toit, R., \& De Bruin, G.P. (2002). The structural validity of Holland's RIASEC model of vocational personality types for young black South African men and women. Journal of Career Assessment, 10(1), 62-77. https://doi.org/10.1177/1069072702010001004

Foxcroft, C., Paterson, H., Le Roux, N., \& Herbst, D. (2004). Psychological assessment in South Africa: A needs analysis. The test use patterns and needs of psychological assessment practitioners. Pretoria: Human Sciences Research Council.

Gevers, J., Du Toit, R., \& Harilall, R. (1995). Manual for the self-directed search questionnaire. Pretoria: Human Sciences Research Council. 
Grant, M.J., \& Booth, A. (2009). A typology of reviews: An analysis of 14 review types and associated methodologies. Health Information \& Libraries Journal, 26(2), 91-108. https://doi.org/10.1111/j.1471-1842.2009.00848.x

Greenhalgh, T., Thorne, S., \& Malterud, K. (2018). Time to challenge the spurious hierarchy of systematic over narrative reviews? European Journal of Clinical Investigation, 48(6), e12931. https://doi.org/10.1111/eci.12931

JvR Academy. (n.d.). $16 p f{ }^{\oplus}$ fifth edition training manual. JvR Academy. Retrieved from https://www.jvracademy.co.za/?dl_name=16PF5_Manual_Academy_colours.pdf

JVR Psychometrics. (2011). Investigating the ethnic equivalence of the 16PF5-SA. JVR Academy, Johannesburg.

JVR Psychometrics. (2016, 29 May). 16PF norm update [Blog post]. Retrieved from https://jvrafricagroup.co.za/16pf5-re-standardised-south-africa/

Kaplan, R.M., \& Saccuzzo, D.P. (2017). Psychological testing: Principles, applications, and issues (9th edn.). Boston, MA: Cengage Learning.

Kgosana, M.C. (2017). Affirmative action and psychometric tests use in the South African National Defense Force: Are they complementary or conflicting forces? Journal of Defense Management, 2, 112-118. https://doi.org/10.4172/2167-0374.1000112

Laher, S., \& Cockcroft, K. (2013). Current and future trends in psychological assessment in South Africa: Challenges and opportunities. In S. Laher \& Cockcroft (Eds.), Psychological assessment in South Africa: Research and applications (pp. 535-552). Wits University Press, Johannesburg.

Laher, S., \& Cockcroft, K. (2017). Moving from culturally biased to culturally responsive assessment practices in low-resource, multicultural settings. Professional Psychology: Research and Practice, 48(2), 115-121. https://doi.org/10.1037/pro0000102

Laher, S., \& Mokone, M. (2008). Exploring the reliability and validity of the DAT-K in Grade 11 learners in a historically disadvantaged school in Johannesburg, South Africa. Journal of Psychology in Africa, 18(2), 249-253. https://doi.org/10.1080/ 14330237.2008.10820193

MacFarlane, M. (2006). Predictors of academic achievement in multilingual learners. Unpublished master's thesis, University of the Witwatersrand, Johannesburg.

Maree, J.G. (2010). Brief overview of the advancement of postmodern approaches to career counseling. Journal of Psychology in Africa, 20(3), 361-367. https://doi.org/ 10.1080/14330237.2010.10820387

Maree, J.G. (2013). Latest developments in career counselling in South Africa: Towards a positive approach. South African Journal of Psychology, 43(4), 409-421. https:// doi.org/10.1177/0081246313504691

Maree, J.G. (2014). Geïntegreerde, kwalitatiewe en kwantitatiewe beroepsvoorligting en beroepskonstruksie vir'n aandagafleibare seun met tegniese belangstelling en aanleg lei tot positiewe resultate: Oorspronklike navorsing. Suid-Afrikaanse
Tydskrif vir Natuurwetenskap en Tegnologie, 33(1), 1-11. https://doi.org/10.4102/ Tydskrif vir Natuu
satnt.v33i1.1183

Maree, J.G. (2015). Blending retrospect and prospect in order to convert challenges into opportunities in career counselling In J G Maree \& A.D. Fabio (Eds.) Exploring new horizons in career counselling: Turning challenge into opportunities Exploring new horizons in career counselling:
(pp. 3-24). Boston, MA: Sense Publishers.

Maree, J.G. (2016). Revitalising career counselling to foster career adaptability and resilience during change and turbulence: part 1 . South African Journal of Higher resilience during change and turbulence: part 1. South Af
Education, 30(3), 1-5. https://doi.org/10.20853/30-3-664

Maree, J.G. (2017). Promoting career development in the early years of a person's life through self-and career construction counselling (using an integrated, qualitative+ quantitative approach): A case study. Early Child Development and Care, 18(4) 437-451. https://doi.org/10.1080/03004430.2017.1365361

Maree, J.G. (2018). Advancing career counselling research and practice using a novel quantitative+qualitative approach to elicit clients' advice from within. South African Journal of Higher Education, 32(4), 149-170. https://doi.org/10.20853/32-4-2558

Maree, J.G. (2019). Group career construction counseling: A mixed-methods intervention study with high school students. The Career Development Quarterly, 67(1), 47-61. https://doi.org/10.1002/cdq.12162

Maree, J.G., \& Beck, G. (2004). Using various approaches in career counselling for traditionally disadvantaged (and other) learners: Some limitations of a new frontier. South African Journal of Education, 24(1), 80-87.

Maree, J.G., \& Morgan, B. (2012). Toward a combined qualitative-quantitative approach: Advancing postmodern career counselling theory and practice. Cyprio Journal of Educational Sciences, 7(4), 311-325.

Maree, J.G., \& Taylor, N. (2016). Development of the Maree Career Matrix: A new interest inventory. South African Journal of Psychology, 46(4), 462-476. https:// doi.org/10.1177/0081246316641558

Maree, J.G., Gerryts, E.W., Fletcher, L., \& Olivier, J. (2019). Using career counselling with group life design principles to improve the employability of disadvantaged
young adults. Journal of Psychology in Africa, 29(2), 110-120. https://doi.org/ young adults. Journal of Psychology
10.1080/14330237.2019.1594646

McDonald, E., \& Van Eeden, R. (2014). The impact of home language on the understanding of the vocabulary used in the South African version of the Sixteen
Personality Factor Questionnaire Fifth Edition. South African Journal of Psychology, Personality Factor Questionnaire Fifth Edition. South African Journ

McMahon, M. (2019). Qualitative career assessment: A higher profile in the 21s century? In J.A. Athanasou \& H.N. Perera (Eds.), International handbook of career guidance (2nd ed., pp. 735-754). Dordrecht: Springer.
McMahon, M., Watson, M., \& Lee, M.C. (2019). Qualitative career assessment: A review and reconsideration. Journal of Vocational Behavior, 110(Part B), 420-432. https://doi.org/10.1016/j.jvb.2018.03.009

McMahon, M., Watson, M., \& Zietsman, L. (2018). Adults changing careers through university education: Making meaning of quantitative career assessment scores through an integrative structured interview. South African Journal of Industrial Psychology, 44(1), 1-10.

Meiring, D., Van De Vijver, A.J.R., Rothmann, S., \& Barrick, M.R. (2005). Construct, item and method bias of cognitive and personality tests in South Africa. South African Journal of Industrial Psychology, 31(1), 1-8. https://doi.org/10.4102/sajip. v31i1.182

Morgan, B. (2010). Career counselling in the 21st century: A reaction article. Journa of Psychology in Africa, 20(3), 501-503. https://doi.org/10.1080/14330237.2010. 10820406

Morgan, B., \& De Bruin, G.P. (2017). Structural validity of Holland's circumplex mode of vocational personality types in Africa. Journal of Career Assessment, 26(2), 275-290. https://doi.org/10.1177/1069072717692747

Morgan, B., De Bruin, G.P., \& De Bruin, K. (2015a). Constructing Holland's hexagon in South Africa: Development and initial validation of the South African career interest inventory. Journal of Career Assessment, 23(3), 493-511. https://doi. org/10.1177/1069072714547615

Morgan, B., De Bruin, G.P., \& De Bruin, K. (2015b). Gender differences in Holland's circular/circumplex interest structure as measured by the South African Career Interest Inventory. South African Journal of Psychology, 45(3), 349-360. https:// doi.org/10.1177/0081246315572514

Naidoo, A.V., Visser, M., De Wet, M., Rabie, S., Van Schalkwyk, I., Boonzaier, M., ... \& Venter, C. (2019). A group-based career guidance intervention for South African high school learners from low-income communities. In J.G. Maree (Ed.), Handbook of innovative career counselling (pp. 665-685). New York: Springer.

Owen, K. (2000). Manual for the differential aptitude test form L. Pretoria: Human Sciences Research Council.

Patel, A.B. (2004). The influence of mode testing (computer based vs. paper \& pencil) on anxiety and test performance. Unpublished master's dissertation. University of the Witwatersrand, Johannesburg.

Prinsloo, C.H., \& Ebersöhn, I. (2002). Fair usage of the 16PF in personality assessment in South Africa: A response to Abrahams and Mauer with special reference to issues of research methodology. South African Journal of Psychology, 32(3), 48-57. https://doi.org/10.1177/008124630203200307

Puchert, J.I., Dodd, N., \& Viljoen, K.L. (2017). Secondary education as a predictor of aptitude: Implications for selection in the automotive sector. South African Journal of Industrial Psychology, 43(1), art. \#1416, 13 pages. https://doi. org/10.4102/sajip.v43i0.1416

Rabie, S., \& Naidoo, A.V. (2019). Validating the adaptation of the first career measure in isiXhosa: The South African Career Interest Inventory-isiXhosa version. South African Journal of Psychology, 49(1), 109-121. https://doi.org/10.1177/0081246318772419

Schepers, J.M., \& Hassett, C.F. (2006). The relationship between the fourth edition (2003) of the locus of control inventory and the sixteen personality factor questionnaire (version 5). South African Journal of Industrial Psychology, 32(2), 9-18. https://doi.org/10.4102/sajip.v32i2.234

Van Eeden, R., \& De Beer, M. (2013). Assessment of cognitive functioning. In C. Foxcroft \& G. Roodt (Eds.), Introduction to psychological assessment in the South African context (4th edn., pp. 147-170). Oxford University Press Southern Africa, Cape Town.

Van Eeden, R., \& Mantsha, T.R. (2007). Theoretical and methodological considerations in the translation of the 16PF5 into an African language. South African Journal of Psychology, 37(1), 62-81. https://doi.org/10.1177/008124630703700105

Van Eeden, R., Taylor, N., \& Prinsloo, C.H. (2013). The sixteen personality factor questionnaire in South Africa. In S. Laher \& K. Cockcroft (Eds.), Psychological assessment in South Africa: Research and applications (pp. 203-217). Wits assessment in South Africa: Res

Van Wijk, C.H., \& Fourie, M. (2017). The appropriateness of using the self-directed search questionnaire in developing countries: A pilot study with South African navy divers. Open Journal of Social Sciences, 5(2), 60-69. https://doi.org/10.4236/ jss.2017.52007

Wallis, T., \& Birt, M. (2003). A comparison of native and non-native English-speaking groups understanding of the vocabulary contained within the 16PF (SA92). South African Journal of Psychology, 33(3), 182-190. https://doi.org/10.1177/008124630303300307

Watson, M.B., Foxcroft, C.D., \& Allen, L.J. (2007). Tracking Holland interest codes: The case of South African field guides. Australian Journal of Career Development, 16(2), 51-59. https://doi.org/10.1177/103841620701600208

Watson, M., \& McMahon, M. (2013). Qualitative career assessment in South Africa. In S. Laher \& K. Cockcroft (Eds.), Psychological assessment in South Africa: Research and applications (pp. 474-487). Wits University Press, Johannesburg.

Watson, M., McMahon, M., \& Longe, P. (2011). Occupational interests and aspirations of rural Black South African children: Considerations for theory, research and practice. Journal of Psychology in Africa, 21(3), 413-420. https://doi.org/10.1080/ 14330237.2011.10820475

Watson, M.B., \& Stead, G.B. (2002). Career psychology in South Africa: Mora perspectives on present and future directions. South African Journal of Psychology, perspectives on present and future directions. South African Journ
32(1), 26-31. https://doi.org/10.1177/008124630203200104 